\title{
Barriers of Professional Autonomy among Arab-Speaking Countries during Covid-19 Pandemic
}

\author{
Zahra Abbas Abdulnabi 1,* and Sadeq AL-Fayyadh²
}

'Department of Adult Nursing, College of Nursing, University of Basrah, Basrah, Iraq.

${ }^{2}$ Chairman, Department of the Adult Nursing, College of Nursing, University of Baghdad, Baghdad, Iraq.

Corresponding Author: Zahra Abbas Abdulnabi (E-mail: zahraa.abbas1202a@conursing.uobaghdad.edu.iq)

(Submitted: 05 April 2021 - Revised version received: 18 April 2021 - Accepted: 22 May 2021 - Published online: 26 June 2021)

\begin{abstract}
Objectives The aims of the study are to determine barriers of nursing autonomy among Arab-Speaking countries during Covid-19 pandemic and to determine difference in professional autonomy levels among Arab-Speaking countries and work place.

Methods Data collected from December 122020 to March 152021 by Google form survey. Cross-sectional design was used in the present study. A purposive sample of 708 nurses who had met the study's inclusion criteria were targeted. Data were analyzed through the use of IBM-Statistical Package for Social Sciences (SPSS) version 17, in which descriptive and inferential statistical measures were employed.

Results The results of the study showed no deference in professional autonomy among Arab speaking countries $P=0.826$ and work place $(P=0.826)$. Most common barriers of professional autonomy are absence of law protecting professional duties (35.6\%) which was perceived by of the study subjects, followed by the policy of health (30.4\%), followed by hospital administration style (26.4\%) and domination or physicians authority (29.9\%)

Conclusion Most common barriers of professional autonomy are absence of law protecting professional duties, the policy of health care sector, domination of physician's authority and hospital administration style. This result reflects highlights the importance of removing all obstacles to upgrade nurse's professional autonomy in the covered Arab-speaking counties.

Keyword Professional Autonomy, Nursing, Nurses, COVID-19, Arabs
\end{abstract}

\section{Introduction}

Independence in decision-making is synonymous with clinical autonomy. Clinical autonomy is defined as the right of nurses to conduct clinical decisions and professional judgment on the basis of their own clinical competence to support the wide spectrum of nursing practices, as distinguished by law enforcement agencies, guidelines, and moral values.

Understanding the idea of clinical decision-making practiceinhealthcaresettingsgivesvisionintoclinicaldecisionmaking practice and gives the nurses an opportunity to choose the best options for problem-solving and to develop the best care plan to evaluate and select nursing interventions. Clinical educators faced challenges to find out how best to develop nurses' cap a bilities in clinical decision-making. ${ }^{2-4}$

Globally, 19 million nurses are using clinical judgment before decision-making. $11 \%$ of the patients in the United Kingdom are suffering from complication due drugs abuse. $34 \%$ of these situations that are critical, $6 \%$ lead to lifelong disabilities and $8 \%$ of patients die. Half of these incidences are avoidable. In absolute terms, healthcare spends 1 billion every year on avoidable incidents. Similarly, in Canada, with $7.5 \%$ of patients experience complications in hospital, $36.9 \%$ of these refereed as avoidable and $20.8 \%$ leading to premature death. Therefore, significant factors behind these statistics are clinical decisions making and professional judgment of health care practitioners, especially by nurses. ${ }^{5}$

Autonomy in clinical decision-making increasing the nurse's responsibility. Nurses who have high level of autonomy provide the best level of care to patients to save their lives and protect them, and this leads to enhanced patient outcomes. ${ }^{6-8}$
In critical care units, the role of nursing is significant, because it varies from other hospital settings. In such challenging settings nurses deal with perplexing and life-threatening conditions, aiming for achieving high quality care., 10 Nurses who work in critical care units and emergency department spend a lot of time with the patient and monitor changes in health status, so the decision of the nurses actually affects the survival of the patient and decides the potential quality of life. For a nurse to practice clinical roles, the standard of decision-making is necessary and is affected by the nature of the surrounding environment. ${ }^{11-13}$

Barriers to nursing autonomy, include however not limited to the fact that the nursing profession has previously depended on the medical profession because of the domination of the health care system by the physician, the disparity between male and female influence, and the style of top-down management. These factors are coupled with the lack of financial, governmental, social and cultural organizational support. In addition, nurses' schooling, regulation, organizational culture, and work-related socialization, which varies across nations, may have an enormous impact on the perception of professional autonomy of nurses, their motivation and ability to achieve professional autonomy in different nursing practices settings; such as critical care, emergency, and traditional care arenas. ${ }^{14-16}$

The current study is the first that covers many Arabic countries. This study will contribute to development of nursing autonomy in clinical decision-making in critical care units, emergency and medical surgical departments, not only in Iraq but also in Arab countries and worldwide. This autonomy is 
considered important to nursing becoming completely independent professional.

\section{Materials and Methods}

\section{Ethical consideration}

The researchers pledge to keep the details of the participants privately, using the collected data without causing any possible harm to the study subjects. The study tool was designed to preserve the right of subject's anonymity. Subjects were given the right to freely participate in the study by signing the electronic consent form of the study.

\section{Design and setting of study}

Cross-sectional design. The study was conducted virtually targeting Arab-speaking nurses who were practicing in critical care units, emergency and medical surgical departments. Beside Iraq, the covered countries were the Hashemite Kingdom of Jordan, Egypt, Palestine and Kingdom of Saudi Arabia.

\section{Instrument of study}

Study instrument consist of two part, first part consist of socio-demographic and professional characteristic, second part consist of Nursing Activity Scale (NAS) which contains 30 items, that explains conditions in which a degree of professional nursing autonomy must be exercised by a nurse.

\section{Statistical analysis}

Data were entered into the IBM-Statistical Package for the Social Sciences (SPSS) version 17 software program and analyzed using descriptive and inferential statistics.

\section{Results and Discussion}

The findings in Table 1 showed that the majority of study participants age group was 26-31 years representing (39.4\%) of the study sample. This result is supported by Maharmeh ${ }^{17}$ a descriptive correlational design aimed to describe Jordanian critical care nurses experience of autonomy in their clinical practice, which indicated that $(62 \%)$ of sample were in age group of 22-30 years. Another study was done by Keshk et al., ${ }^{18}$ found in their study that the highest percent of study participant (50\%) within age group (26-34). Data were collected by using Google form survey whereas young individuals were the most common persons who responded. These result agreed with other study, which showed that young individuals are spending a significant amount of their time using social media. ${ }^{19}$

Regarding to level of education, findings of the study indicated that more than half of study sample were holding Bachelor's degree (57.6\%). Another study conducted among nurses in the southeast of Iran, found that most of nurses were holding Bachelor's degree (97\%) too. ${ }^{20}$ Another study conducted in Intensive Care Unit (ICU) of Islamic republic of Iran, showed that more than half (85\%) of nurses who were participants in the study were holding Bachelor's degree. ${ }^{21}$

In the present study (55.4\%) of study sample were male. Another study indicated that the highest percentage of study respondents were male (54.2\%). ${ }^{22}$ Furthermore, the challenging nature of nursing profession has hindered females

\begin{tabular}{|c|c|c|c|c|}
\hline \multirow{6}{*}{ 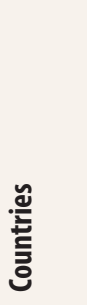 } & Characteristics & $\mathbf{F}$ & Percent & Valid \% \\
\hline & Iraq & 482 & $\underline{68.1}$ & 68.1 \\
\hline & Egypt & 113 & 16.0 & 16.0 \\
\hline & Jordon & 39 & 5.5 & 5.5 \\
\hline & KSA & 39 & 5.5 & 5.5 \\
\hline & Palestine & 35 & 4.9 & 4.9 \\
\hline \multirow{4}{*}{ 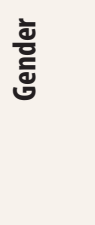 } & Male & 392 & $\underline{55.4}$ & 55.4 \\
\hline & Female & 316 & 44.6 & 44.6 \\
\hline & $20-25$ & 224 & 31.6 & 31.6 \\
\hline & $26-31$ & 279 & $\underline{39.4}$ & 39.4 \\
\hline \multirow{6}{*}{ 苋 } & $32-37$ & 116 & 16.4 & 16.4 \\
\hline & $38-44$ & 71 & 10.0 & 10.0 \\
\hline & $45-51$ & 16 & 2.3 & 2.3 \\
\hline & $52-58$ & 2 & 0.3 & 0.3 \\
\hline & Diploma in Nursing & 190 & 26.8 & 26.8 \\
\hline & Bachelor's in nursing & 408 & $\underline{57.6}$ & 57.6 \\
\hline \multirow{3}{*}{ 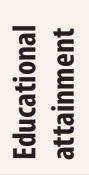 } & Master in nursing & 102 & 14.4 & 14.4 \\
\hline & Doctorate in nursing & 8 & 1.1 & 1.1 \\
\hline & Total & 708 & 100.0 & 100.0 \\
\hline
\end{tabular}

The underlined numbers in Table 1, represent the highest percentages of the selected variables. In which, more than half (55.4\%) of the study sample were males. More than quarters (39.4\%) of the study sample were classified as adult individuals within age range of 26 - 31 years. Furthermore, most of them (57.6\%) were holding Bachelor's degree. Concerning the nurses' country, the highest percentage (68.1\%) of the study participants were from Iraq.

from joining nursing, which created a critical imbalance as shown in Iraqi Nursing Syndicate (INS)'s statistics as male:female nurse ratio is $75: 25 .{ }^{23}$ This ratio was reflected by the descriptive statistics of sample demographics, which were, more male nurses (55.4\%) participated in this study than females $(44.6 \%)$. The study findings showed that most study sample (68.1\%) were from Iraq due to the fact that this research was conducted in Iraq and Iraqi nurses were the most responsive subjects to the online questionnaire than other Arabspeaking countries.

According to Table 2 that is related to professional characteristics, represents highest percent of study participants (75.4\%) were working in governmental sector. Another study was conducted to examining the level of professional autonomy as well as its predictor and outcomes among practicing nurses in the Phillippins, found that (73.5\%) of study participants were working in public sector. ${ }^{24}$ These results were not surprising due to the fact that Arab-speaking countries health sector is public service sector, unlike Western countries, where the majority are capital institutions.

About working place, the majority of the study sample were working in critical care units (37.7\%). In contrast, Amini et al., ${ }^{25}$ nurses' autonomy level in teaching hospitals and its relationship with the underlying factors showed that more than half of their study samples (49.2\%) were working in 


\begin{tabular}{|c|c|c|c|}
\hline \multicolumn{2}{|c|}{ Professional Characteristics } & \multirow{2}{*}{$\begin{array}{c}\mathbf{F} \\
534\end{array}$} & \multirow{2}{*}{$\begin{array}{c}\% \\
75.4 \\
\end{array}$} \\
\hline Working sector & Governmental Sector & & \\
\hline & Private Sector & 74 & 10.5 \\
\hline & Both Sectors & 100 & 14.1 \\
\hline \multirow[t]{5}{*}{ Working place } & Emergency Department & 215 & 30.4 \\
\hline & Medical Department & 110 & 15.5 \\
\hline & Surgical Department & 107 & 15.1 \\
\hline & Critical Care Units & 267 & $\underline{37.7}$ \\
\hline & Burns Care Department & 9 & 1.3 \\
\hline \multirow{6}{*}{$\begin{array}{l}\text { Years of } \\
\text { Experience in } \\
\text { Hospital }\end{array}$} & 1 - 5 Years & 429 & $\underline{60.6}$ \\
\hline & $6-10$ Years & 155 & 21.9 \\
\hline & $11-15$ Years & 67 & 9.5 \\
\hline & $16-20$ Years & 42 & 5.9 \\
\hline & $21-25$ Years & 12 & 1.7 \\
\hline & $26-30$ Years & 3 & .4 \\
\hline \multirow{6}{*}{$\begin{array}{l}\text { Years of } \\
\text { Experience in } \\
\text { Recent Unit }\end{array}$} & $1-5$ Years & 520 & $\underline{73.4}$ \\
\hline & $6-10$ Years & 133 & 18.8 \\
\hline & $11-15$ Years & 30 & 4.2 \\
\hline & $16-20$ Years & 17 & 2.4 \\
\hline & $21-25$ Years & 7 & 1.0 \\
\hline & $26-30$ Years & 1 & .1 \\
\hline \multirow[t]{2}{*}{ Working Shift } & Morning Shift & 453 & $\underline{64.0}$ \\
\hline & Evening Shift & 255 & 36.0 \\
\hline \multirow[t]{2}{*}{$\begin{array}{l}\text { Professional } \\
\text { Roles }\end{array}$} & $\begin{array}{l}\text { Nurse Executing an } \\
\text { Administrative Role }\end{array}$ & 166 & 23.4 \\
\hline & Bedside Nurse & 542 & $\underline{76.6}$ \\
\hline \multirow{2}{*}{$\begin{array}{l}\text { Experience } \\
\text { development }\end{array}$} & Yes & 680 & $\underline{96.0}$ \\
\hline & No & 28 & 4.0 \\
\hline \multirow{7}{*}{$\begin{array}{l}\text { Source of } \\
\text { Knowledge }\end{array}$} & Social Media Platforms & 146 & $\underline{20.6}$ \\
\hline & Scientific Websites & 43 & 6.1 \\
\hline & Audiovisual media & 12 & 1.7 \\
\hline & Books \& scientific journals & 89 & $\underline{12.6}$ \\
\hline & Professional colleagues & 59 & 8.3 \\
\hline & All of the Above & 330 & $\underline{46.6}$ \\
\hline & Not Apply to me & 29 & 4.1 \\
\hline \multirow[t]{2}{*}{$\begin{array}{l}\text { Participation } \\
\text { in training } \\
\text { program of } \\
\text { professional } \\
\text { autonomy }\end{array}$} & Yes & 350 & 49.4 \\
\hline & No & 358 & $\underline{50.6}$ \\
\hline \multirow{3}{*}{$\begin{array}{l}\text { No. of Beds in } \\
\text { Unit }\end{array}$} & $1-5$ & 156 & 22.0 \\
\hline & $5-10$ & 217 & 30.6 \\
\hline & $>10$ beds & 335 & $\underline{47.3}$ \\
\hline \multirow{3}{*}{$\begin{array}{l}\text { No. of the } \\
\text { patient in work } \\
\text { shift }\end{array}$} & one Patients & 49 & 6.9 \\
\hline & Two Patients & 105 & 14.8 \\
\hline & $>3$ patients & 554 & $\underline{78.2}$ \\
\hline
\end{tabular}

\begin{tabular}{|c|c|c|c|}
\hline \multicolumn{2}{|c|}{ Professional Characteristics } & \multirow{2}{*}{$\begin{array}{c}\mathbf{F} \\
427\end{array}$} & \multirow{2}{*}{$\begin{array}{c}\% \\
60.3 \\
\end{array}$} \\
\hline No. of nurses in & $1-5$ Nurses & & \\
\hline work shift & $5-10$ Nurses & 190 & 26.8 \\
\hline & $>10$ nurses & 91 & 12.9 \\
\hline \multirow{3}{*}{$\begin{array}{l}\text { Having Nursing } \\
\text { Association }\end{array}$} & Yes & 372 & $\underline{52.5}$ \\
\hline & No & 181 & 25.6 \\
\hline & Not Sure & 155 & 21.9 \\
\hline \multirow{3}{*}{$\begin{array}{l}\text { Nursing } \\
\text { Association } \\
\text { Membership }\end{array}$} & Yes & 178 & 25.1 \\
\hline & No & 366 & $\underline{51.7}$ \\
\hline & Not Apply to me & 164 & 23.2 \\
\hline \multirow{2}{*}{$\begin{array}{l}\text { Have Job } \\
\text { Description }\end{array}$} & Yes & 360 & $\underline{50.8}$ \\
\hline & No & 348 & 49.2 \\
\hline \multirow{3}{*}{$\begin{array}{l}\text { Applying Job } \\
\text { Description }\end{array}$} & Yes & 247 & 34.9 \\
\hline & No & 297 & $\underline{41.9}$ \\
\hline & Not Apply to me & 164 & 23.2 \\
\hline \multirow{2}{*}{$\begin{array}{l}\text { Awareness of } \\
\text { Job Description }\end{array}$} & Yes & 550 & $\underline{77.7}$ \\
\hline & No & 158 & 22.3 \\
\hline \multirow{3}{*}{$\begin{array}{l}\text { Professional } \\
\text { Autonomy in } \\
\text { Curriculum }\end{array}$} & Yes & 484 & $\underline{68.4}$ \\
\hline & No & 224 & 31.6 \\
\hline & Total & 708 & 100.0 \\
\hline
\end{tabular}

The underlined numbers in Table 2, represent the highest percentages of the selected variables. In which, the majority of the respondents were working in governmental sector (75.4\%) at the time of data collection. About (37.7\%) were practicing nursing in critical care units. Furthermore, most of them were working in morning shift (64.0\%). 1-5 years' experience in recent unit was the dominant choice of the study subjects, representing (73.4\%). Most nurses were employed as bedside nurses (76.6\%). The highest percentage of subject's experience in the hospital was spotted as (6-10 years) representing (60.6\%). Of equal importance, (96.0\%) of study participants were actively working on developing their professional autonomy experience. Social media (20.6\%), books and scientific journals (12.6\%) were the most common sources of knowledge, by which nurses were working to develop their competencies about professional autonomy. More than half (50.6\%) of the study respondents were not previously participated in training programs of professional autonomy. The highest percentages of the served bed in the targeted units were more than ten, representing (47.3\%). On the other hand, the highest percentage (78.2\%), representing the number of the patient in work shift, which is more than three for each nurse. About (60.3\%), representing 1-5 nurses, was the highest percentage of nurse's number during work shift. The majority of respondents indicated having an active nursing association membership (51.7\%), and (50.8\%) indicated having a job description. However, only (41.9\%) of them were able to apply job description. About three quarters of the study sample (77.7\%) indicated having job description awareness. Surprisingly, only (68.4\%) of respondents reported that professional autonomy was covered during their academic preparation curriculum.

non-critical care units. The findings of this study have indicated that the majority of study sample were practicing in critical care units due to the fact that data collection phase was conducted during Covid-19 pandemic, in which most units in the hospital were transformed to be critical care units to accommodate the increasing numbers of patient.

Concerning working shift, most of study subjects were work during morning shift (64.0\%). Another study conducted 
to assess nurse's work autonomy on patient care and unit operation which stated that (59.8\%) of sample were working in day shift. ${ }^{26}$ This result is not surprising due to the fact that the number of the nurses who work in morning shift is more than night shift. This can be explained by the fact that most nurses preferred working in morning more than night shift, due to administrative and duties nature factors. Morning shift provide opportunities for sleeping, learning and developing teamwork skill from other health care providers that are available. Furthermore, competent nurse peers provided reassurance and direction in making important patient decisions. Indeed, nurses made patient decisions based on facts derived by their own skill or knowledgeable peers rather than data or hospital procedures. ${ }^{27-29}$

The study found that the highest percentage in terms of years of experience in hospital and recent unit of study participants between 1-5 years (73.4\%). These findings agreed with $^{30}$, which indicated that the highest percentage of experience years was less than ten years (51.0\%). These results were not surprising due to the fact that the majority of study participants were within age group 26-30 years (39.4\%).

Professional role is another variable that this study has highlighted, whereas the majority of the study participants were bedside nurses $(76.6 \%)$. This finding is congruent with Labrague et al., ${ }^{24}$ in which the highest percent of study sample were practicing nursing as a staff nurse position (84.7\%). This result was not surprising due to the fact that staff nurses form the majority of heath care system when compared with nurses who hold managerial positions.

The results of the present study indicated that more than half $(50.6 \%)$ of study respondents were not previously participated in training programs of professional autonomy. This result is similar to Allahkhshian et al. ${ }^{21}$ in which they found that there was not any training program about the concept of professional autonomy offered to nurses. This highlights the huge gab and emphasizes the extreme necessity of conducting such educational program to enhance nurse's awareness about their standard professional role autonomy boundaries. Unfortunately, these results were not surprising due to the fact that the majority of study respondents are from Iraq, which do not emphasize an importance of the professional independence of nursing and the necessity of training programs that clarify the limits of professional independence and the role of the nurse in order to provide the best care to the patient.

Surprisingly, only $(68.4 \%)$ of respondents reported that professional autonomy was covered during their academic preparation as a topic in the nursing curriculum. In contrast, (Allahkhshian et al. ${ }^{21}$ indicated that nursing autonomy and professionalism in the nursing were not emphasized in the nursing core curriculum.

Most study participants (96.0\%) had indicated that they work on developing their knowledge \& experience about nursing professional autonomy. They highlighted many sources to seek development including, social media platform (20.6\%), books and scientific journal (12.6\%). These were most common source of knowledge seeking platforms. The highest percentage of the bed in unit was more than ten, representing $(47.3 \%)$. On the other hand, the highest percentage $(78.2 \%)$, representing the number of the patient in work shift, which is more than three for each nurse, while global nurses patients ratio $1: 1$ as recommended in critical care units.
About (60.3\%), representing 1-5 nurses is the highest percentage of nurse's number during work shift. Having high numbers of admitted clients, nursing staff shortage, is not surprising because of data collected phase was conducted during Covid-19 pandemic. That lead to increase work load and decreasing number of health care providers in the world due to the fact that nurses being the front line of fighting the pandemic has led to high morbidity and mortality rate among them. Unfortunately, no reliable statistics about number of nurse's death rate due to coronavirus are available to be reported.

The majority of respondents indicated having a nursing association membership (51.7\%), have nursing association (52.5\%) and (50.8\%) indicated having a job description. However, only (41.9\%) of them were able to apply job description. About three quarters of the study sample $(77.7 \%)$ indicated having job description awareness. At the end of this section, it is important to notice that the present study is the first that deals with the aforementioned variables, which makes its findings unique in terms of highlighting new gaps that need to be addressed effectively.

As presented in Table 3, the highest percentages of the perceived barriers of nursing professional autonomy according to the subjects of the current study were the absence of law(s), describing and protecting professional duties (35.6\%), followed by hospital administration style (26.4\%), followed by the policy of the health institution (30.4\%), followed by domination of physician's authority (29.9\%). These were the dominant barriers that may have prevented nurses from authenticating professional autonomy. These findings are supported by a study which found that physician-dominated of the health care system and autocratic hospital management were the most common obstacles of nursing autonomy. ${ }^{21}$ Other studies indicated that intra-professional conflict such as

Table 3. Barriers of applying professional autonomy

\begin{tabular}{|c|c|c|}
\hline Perceived barriers & f & $\%$ \\
\hline Hospital administration & 187 & $\underline{26.4}$ \\
\hline Unit Manager & 78 & 11.0 \\
\hline Work Load & 121 & 17.1 \\
\hline $\begin{array}{l}\text { Absence of legislations protecting professional } \\
\text { duties }\end{array}$ & 252 & $\underline{35.6}$ \\
\hline Colleagues & 52 & 7.3 \\
\hline $\begin{array}{l}\text { Low confidence in abilities to execute } \\
\text { professional duty independently }\end{array}$ & 6 & 0.8 \\
\hline $\begin{array}{l}\text { Awareness lack of nursing authority \& } \\
\text { professional responsibilities limit }\end{array}$ & 64 & 9.0 \\
\hline Health care institution dominant policy & 215 & 30.4 \\
\hline Domination of physician's authority & 212 & $\underline{29.9}$ \\
\hline All of the aforementioned barriers & 91 & 12.9 \\
\hline Not apply to me & 182 & 25.7 \\
\hline
\end{tabular}

The underlined numbers in Table 3, represent the highest percentages of the perceived barriers according to nurses' choices. In which, absence of law protecting professional duties (35.6\%), hospital administration style (26.4\%), the applied policy of the health institution (30.4\%) and the domination or authority of physicians (29.9\%), were the prevailing barriers that may have prevent nurses from authenticating professional autonomy. 
Table 4. Differences in the professional autonomy levels in respect to nurses' countries

\begin{tabular}{|c|c|c|c|c|c|c|}
\hline \multirow{4}{*}{$\begin{array}{l}\text { Professional } \\
\text { Autonomy* } \\
\text { Country }\end{array}$} & $\begin{array}{l}\text { Character- } \\
\text { istics }\end{array}$ & $\begin{array}{l}\text { Sum of } \\
\text { Squares }\end{array}$ & df & $\begin{array}{l}\text { Mean } \\
\text { Square }\end{array}$ & F & Sig. \\
\hline & $\begin{array}{l}\text { Between } \\
\text { Groups }\end{array}$ & .425 & 4 & $\underline{0.106}$ & $\underline{0.543}$ & $\underline{0.704}$ \\
\hline & $\begin{array}{l}\text { Within } \\
\text { Groups }\end{array}$ & 137.618 & 703 & 0.196 & & \\
\hline & Total & 138.043 & 707 & & & \\
\hline \multirow{3}{*}{$\begin{array}{l}\text { Professional } \\
\text { Autonomy* } \\
\text { Working } \\
\text { place }\end{array}$} & $\begin{array}{l}\text { Between } \\
\text { Groups }\end{array}$ & 0.294 & 4 & $\underline{0.074}$ & $\underline{0.376}$ & $\underline{0.826}$ \\
\hline & $\begin{array}{l}\text { Within } \\
\text { Groups }\end{array}$ & 137.749 & 703 & .196 & & \\
\hline & Total & 138.043 & 707 & & & \\
\hline
\end{tabular}

Analysis of Variance (ANOVA) test in Table 4 indicates there is no a statistically significant difference of professional autonomy levels in covered Arab-speaking countries (mean $=0.106, F=0.543, P=0.704$ ) and the working place $($ mean $=0.074, F=0.376, P=0.826)$.

absence of respect, trust and collaboration between physicians and nurses were barriers that must be addressed to upgrade nurse's professional autonomy. Nurses will be empowered when having the confidence to step forward embracing their professional and ethical authority through creating collaborative relationships with physicians. ${ }^{31-34}$ These study findings also supported by structural element of empowerment theory which suggested that an organization must provide authority, support and resources to employees that are required for achieving the organizational objectives. ${ }^{3}$

Analysis of variance (ANOVA) test in Table 4 indicated that there was no statistically significant difference in nurses professional autonomy between Arab-speaking countries (mean $=0.106, \mathrm{~F}=0.543, P=0.704$ ), and working place (mean $=0.074, \mathrm{~F}=0.376, P=0.826)$. These results may explained by the fact that Covid-19 pandemic had a global impact on health care systems of the covered countries such as increase number of patient admitted to hospital and decline number of health care professionals; especially nurses, increase work load, and economic impact, which lead decrease resources and necessary supply.

\section{Conclusions}

Most common barriers of professional autonomy are absence of law protecting professional duties, the policy of health care sector, domination of physician's authority and hospital administration style. This result reflects highlights the importance of removing all obstacles to upgrade nurse's professional autonomy in the covered Arab-speaking counties.

\section{Recommendation}

Support and encourage nurses to exercises autonomy in clinical practice by providing law that protects them, standard and policy to apply their practice in work field. Improve collaborative relationship between nurses and physicians to enhance patient outcomes, decrease physicians' domination and improve nursing autonomy. Strong united nursing groups and professional associations are also required to drive forward in self-government in nursing.

\section{Limitations}

Limited access to the internet services was one of the major obstacles that have limited the participation rate. Of equal importance, a significant percentage of medical-surgical nurses were affected by the Covid-19 pandemic during data collection phase, which also limited the participation rate in the study.

\section{Funding Information}

The budget of this research work was not support by any governmental or non-governmental organization. The author of this manuscript covered all the research work-related expenses.

\section{Conflicts of Interest}

None.

\section{References}

1. Kramer, M., \& Schmalenberg, C.E. The practice of clinical autonomy in hospitals:20000 nurses tell their story. Critical Care Nurse. 2008;28:58-71.

2. Shin, K. R. Critical thinking ability and clinical decision-making skills among senior nursing students in associate and baccalaureate programmes in Korea. Journal of advanced nursing. 1998;28:58-71.

3. Higuchi, K. A. S., \& Donald, J. G. Thinking processes used by nurses in clinical decision making. Journal of Nursing Education. 2002:41:145-153.

4. Bohinc, M., \& Gradisar, M. Decision-making model for nursing. The Journa of Nursing Administration. 2003:33:627-629.

5. Thompson C. International Journal of Nursing Studies www.elsevier.com/ ijns 2013.

6. Keith, L., \& Cianelli, R. Exploring the concept of nurse engagement related to patient experience. Horiz Enferm. 2014;25:109-113.

7. Rafferty, A. M., Ball, J., \& Aiken, L. H. Are teamwork and professional autonomy compatible, and do they result in improved hospital care?. BM Quality \& Safety. 2001;10:ii32-ii37.

8. Watson, L. M. Leaderships influence on job satisfaction. Radiologic Technology. 2009:80:297-308.

9. Kelly, D. M., Kutney-Lee, A., McHugh, M. D., Sloane, D. M., \& Aiken, L. H. Impact of critical care nursing on 30-day mortality of mechanically ventilated older adults. Critical care medicine. 2014:42:1089.

10. Ulrich, B. T., Lavandero, R., Woods, D., \& Early, S. Critical care nurse work environments 2013: A status report. Critical care nurse. 2014;34:64-79.

11. Boev, C. The relationship between nurses' perception of work environment and patient satisfaction in adult critical care. Journal of Nursing Scholarship. 2012;44:368-375

12. Backes, M. T. S., Erdmann, A. L., \& Büscher, A. The living, dynamic and complex environment care in intensive care unit. Revista latino-americana de enfermagem. 2015:23:411-418.

13. Cishahayo, E., Nankundwa, E., Sego, R., \& Bhengu, B. Burnout among nurses working in critical care settings: a case of a selected tertiary hospital in Rwanda. International Journal of research in medical sciences. 2017;5:51215128 .

14. Iliopoulou, K. K., \&While, A. E. Professional autonomy and job satisfaction: survey of critical care nurses in mainland Greece. Journal of advanced nursing. 2010;66:2520-2531.

15. Traynor, M., Boland, M., \& Buus, N. Professional autonomy in 21st century healthcare: Nurses' accounts of clinical decision-making. Social science \& medicine. 2010;71:1506-1512.

16. Baykara, Z. G., \& Sahinoğlu, S. An evaluation of nurses' professional autonomy in Turkey. Nursing ethics. 2014;21:447-460. 
17. Maharmeh, M. Understanding critical care nurses' autonomy in Jordan. Leadership Health Services. 2017;30:432-442.

18. Keshk, L. I., Qalawa, S. A. A., \& Aly, A. A. Clinical decision-making experience of the critical care nurses' and its effect on their job satisfaction:

Opportunities of good performance. American Journal of nursing research. 2018;6:147-157.

19. Valdez, G. F. D., Cayaban, A. R. R., Al-Fayyadh, S., Korkmaz, M., Obeid, S., Sanchez, C. L. A. \& Cruz, J. P. The utilization of social networking sites, their perceived benefits and their potential for improving the study habits of nursing students in five countries. BMC nursing. 2020;19:1-14.

20. Jahromi et al. (2015)

21. Allahkhshian, M., Alimohammadi, N., Taleghani, F., Nik, A. Y., Abbasi, S., \& Gholizadeh, L. Barriers to intensive care unit nurses' autonomy in Iran: A qualitative study. Nursing outlook. 2016;65:392-399.

22. Gizaw, A., Kidane, B., Negese, D., \& Negassa, E. Factors affecting clinical decision-making practice among nurses working in Jimma University Medical Center, Jimma southwest Ethiopia. Ann Nurs Pract. 2018;5:1094

23. Iraqi Nursing Syndicate. Nursing in Iraq record. US: Official record of INS. 2014.

24. Labrague, L. J., McEnroe-Petitte, D. M., \&Tsaras, K. Predictors and outcomes of nurse professional autonomy: A cross-sectional study. International journal of nursing practice. 2019;25:e12711.

25. Amini, K., Negarandeh, R., Ramezani-Badr, F., Moosaeifard, M., \& Fallah, R. Nurses' autonomy level in teaching hospitals and its relationship with the underlying factors. International journal of nursing practice. 2015;21:52-59.

26. Mrayyan, M. T. American nurses' work autonomy on patient care and unit operations. British Journal of Nursing. 2005;14:962-967

27. Seright, T. J. Clinical decision-making of rural novice nurses. Rural Remote Health. 2011;11:1726.

28. Cappelletti, A., Engel, J. K., \& Prentice, D. Systematic review of clinical judgment and reasoning in nursing. Journal of Nursing Education. 2014;53:453-458.
29. Samuriwo, R., \& Dowding, D. Nurses' pressure ulcer related judgements and decisions in clinical practice: A systematic review. International Journal of Nursing Studies. 2014;51:1667-1685.

30. Mohamed, N. T. Relationship between leadership styles and clinical decision-making autonomy among critical care nurses. Egyptian Nursing Journal. 2018;15.

31. Hartog, C. S., \& Benbenishty, J. Understanding nurse -physician conflicts in the ICU. Intensive care medicine. 2015;41:331-333.

32. Avila, L. I., Silveira, R. S. D., Lunardi, V. L., Fernandes, G. F. M., Mancia, J. R., \& Silveira, J. T. D. Implications of the visibility of professional nursing practices. Revista gaucha de enfermagem. 2013;34:102-109.

33. Dorgham, S. R., \& Al-Mahmoud, S. Leadership styles and clinicaldecision making autonomy among critical care nurses: A comparative study. Journal of Nursing and Health Science. 2013;1:71-83.

34. Georgiou, E., Papathanassoglou, E. D., \& Pavlakis, A. Nurse-physician collaboration and associations with perceived autonomy in Cypriot critical care nurses. Nursing in critical care. 2017;22:29-39.

35. Kanter, R.M. (1993). Men and women of the corporation (2nd ). New York: Basic Books.

36. Suominen, T., Leino-Kilpi, H., Merja, M., Doran, D. I., \& Puukka, P. Staff empowerment in Finnish intensive care units. Intensive and Critical Care Nursing. 2001;17:341-347.

37. Hoffman, K., Duffield, C., \& Donoghue, J. Barriers to clinical decision-making in nurses in Australia. Australian Journal of Advanced Nursing. 2004;21:8-13.

38. Taylor, M. A. The Relationship between autonomy and job satisfaction among registered nurses. Master Thesis. University of New Hampshire, Durham. 2008.

39. Schutzenhofer, K. K. The measurement of professional autonomy. Journal of professional nursing. 1987;3:278-283.

40. Motamed-Jahromi, M., Jalali, T., Eshghi, F., Zaher, H., \& Dehghani, L. Evaluation of professional autonomy and the association with individual factors among nurses in the Southeast of Iran. Journal of Nursing and Midwifery Sciences. 2015;2:37-42. 